\title{
História, imprensa e a construção da realidade durante o regime militarno Brasil (1964/1985)
}

Jefferson Gomes Nogueira*

Durante quase todo o período do Regime Militar no Brasil (1964/1985) os meios de comunicação foram censurados e/ou utilizados pelo aparato estatal repressor, como eficiente mecanismo de controle social. A ação dos censores não se limitava a coibir a publicação de notícias contrárias ao regime, mas se destinava, também, a divulgar fatos que fossem úteis na construção da realidade que convinha ao Sistema. Através da análise da produção histórica sobre a imprensa e o regime militar no Brasil, objetivamos demonstrar como a imprensa escrita foi utilizada nesse processo da "construção da realidade" durante os longos 21 anos de regime militar no Brasil.

Palavras - chave: Regime militar - imprensa - censura.

During the whole period of the military regime in Brazil (1964/1985) the media were

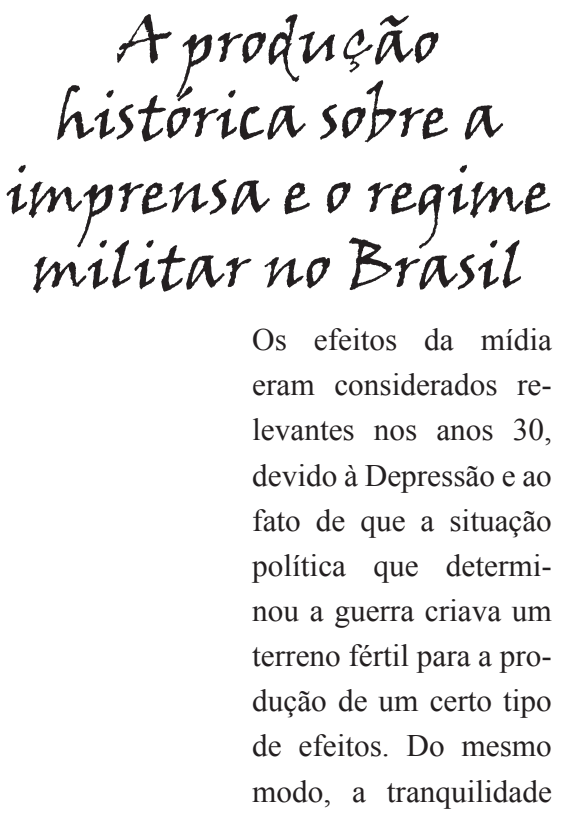

historica sobre a imprensa e regime militar no Brasil

Os efeitos da mídia cram considerados redevido à Depressão e ao fato de que a situação política que determinou a guerra criava um terreno fértil para a produção de um certo tipo modo, a tranquilidade

\footnotetext{
*Mestre em História Social das Relações Políticas. Mestrando em Educação/ Universidade Federal do Mato Grosso do Sul. historiasocial2009@yahoo.com.br
} 
censored and / or used by the repressive state apparatus, as an efficient mechanism of social control. The action of the censors did not just restrain the publication of news contrary to the scheme, but was also intended to disclose facts that were useful in the construction of reality that suited the system. Through analysis of historical pro- duction on the press and the military regime in Brazil, we aimed to demonstrate how the printing press was used in the process of "construction of reality" during the 21 long years of military rule in Brazil.

Keywords: Military regime - media - censorship.

dos anos 50 e 60 conduzia a um modelo de efeitos limitados. Ao final dos anos 60, um período de conflitos, tensões políticas e crise econômica contribuiu para tornar a estrutura social fundamentalmente vulnerável e permeável à comunicação dos meios de massa ${ }^{1}$

A ditadura militar implantada no Brasil em março/abril 1964, através de um golpe civil/militar ${ }^{2}$, mergulhou a sociedade brasileira num contexto histórico marcado por perseguições políticas, incertezas, medos e abusos de autoridade e poder de toda ordem. Os atores políticos envolvidos naquele episódio histórico, principalmente os militares de alta patente, dão suas versões sobre os fatos através de depoimentos e publicações próprias, tentando justificar a necessidade de se chegar ao extremo que foi a tomada do poder através de um golpe.

A produção histórica sobre acontecimentos posteriores ao golpe civil/ militar de 1964 marca uma nova fase de estudos sobre aquele período e possui suas peculiaridades. Essa produção historiográfica está inserida no contexto da chegada da chamada Nova História ao país, o que "[...] não viria a ser uma produção fortemente influenciada pelo marxismo ou pela segunda fase dos Annales ${ }^{3 "}$. ${ }^{4}$

${ }^{1}$ Carey, 1978, apud. Wolf, 2003, p.49.

${ }^{2} \mathrm{O}$ termo Golpe civil/militar é utilizado pelo historiador Carlos Fico devido coalizão de forças, civis e militares, que culminou com a derrubada do Presidente João Goulart.

${ }^{3}$ A revista dos Annales foi fundada em 1929, através de um movimento surgido na França tendo como principais mentores Marc Bloch e Lucian Febvre.

${ }^{4}$ FICO, Carlos. As controvérsias sobre 1964 e a ditadura militar. In: Revista Brasileira de História. São Paulo, v. 24, n. 47, 2004, p. 40. 
Abandonando explicações fundadas em conceitos como os de 'classe social', 'modo de produção', 'estrutura econômica' ou 'estrutura social', os historiadores do que se convencionou chamar de "Nova História" buscavam uma estratégia cognitiva (mais do que uma perspectiva teórico-conceitual) que enfatizasse o indivíduo, seu cotidiano, suas emoções, sua 'mentalidade', sua 'trajetória de vida' etc., opções que, obviamente, não incidiram apenas sobre os estudos relativos à ditadura militar, mas sobre todo o escopo de estudos históricos aqui e alhures. ${ }^{5}$.

Apesar de se tratar de uma história muito recente, que tem muitos pormenores ainda não esclarecidos devido à falta de acesso às fontes documentais que poderiam elucidar melhor muitos acontecimentos daquele período $^{6}$, principalmente os ligados aos grupos de guerrilha que aderiram à luta armada como forma de oposição ao regime militar, há uma vasta produção histórica sobre o golpe de 1964 e o regime autoritário implantado e consolidado através dos diversos Atos Institucionais (AI). Segundo levantamento do Grupo de Estudos sobre a Ditadura Militar (GEDM) da Universidade Federal do Rio de Janeiro, entre os anos de 1971 e 2000, foram produzidos diversos trabalhos acadêmicos, sendo que destes “"[... 214 teses de doutorados e dissertações de mestrados sobre a história da ditadura militar, 205 delas no Brasil e as restantes no exterior"’

Toda essa produção está relacionada ao interesse e ao fascínio que o tema suscita, pois quanto mais se pesquisa e estuda o regime militar, mais se percebe que há muito a ser esclarecido. O crescimento dos estudos que tomaram a temática da ditadura militar, da luta armada e do pensamento militar brasileiro, abrange focos de diferentes interesses:

[...] os principais focos de interesses foram os movimentos sociais urbanos (27 trabalhos), os temas da arte e da cultura (também com 27 trabalhos), a economia (25) e os assuntos relacionados à esquerda e à

\section{${ }^{5}$ Idem.}

${ }^{6}$ Espera-se que com os trabalhos da Comissão Nacional da Verdade possam ser disponibilizados documentos e depoimentos mais elucidativos sobre o que aconteceu naquele período histórico.

${ }^{7}$ FICO, Carlos. Op. cit., p. 40-41. 
oposição em geral (20 teses e dissertações). Em seguida vem a imprensa (15), a censura (13), a crônica dos diversos governos (11), o movimento estudantil (8) e o estudo do próprio golpe (6), entre outros temas ${ }^{8}$.

Carlos Fico destaca que a grande presença de teses e dissertações sobre os movimentos sociais urbanos talvez indique a transição entre o antigo predomínio acadêmico do marxismo e a voga em torno da Nova História. "Nas teses sobre o movimento operário a partir do ano de 2000, apresentam abordagens típicas da "Nova História", como a memória e as práticas culturais ou o recurso a fontes não convencionais como a charge".

Em Versões e Ficções: o Sequestro da História ${ }^{10}$, temos o relato de autores que participaram ativamente da luta armada, numa versão crítica da idéia do romantismo revolucionário que está contida em alguns livros e filmes, como é o caso de "O que é isso companheiro?", do Deputado Federal e jornalista Fernando Gabeira. Segundo João Quartim de Moraes, esse livro constitui um "antídoto contra a banalização e pasteurização da resistência revolucionária à ditadura militar".

Na história contata pela esquerda, Carlos Fico destaca que depoimentos como os de Fernando Gabeira e Alfredo Sirkis contribuíram para a mitificação da figura do ex-guerrilheiro, por vezes tido como romântico ou tresloucado, diluído no contexto cultural de rebeldia típico dos anos 60 , algo que não condiz com as efetivas motivações da assim chamada "luta armada".

Com a obra Combate nas trevas. A esquerda Brasileira: Das ilusões perdidas à luta armada, Jacob Gorender ${ }^{11}$ sempre procurou fazer o que muitos militantes marxistas brasileiros pregavam mas não conseguiam, que

\footnotetext{
${ }^{8}$ Idem, p. 41.

${ }^{9}$ Idem.
}

${ }^{10}$ VERSÕES E FICÇÕES: o Sequestro da História reúne textos sobre a ditadura militar no Brasil, de autores que acompanharam os fatos históricos referentes aquele período, dentre eles, alguns participaram de ações armadas, como o sequestro do embaixador norte-americano em 1969. Editora Fundação Perseu Abramo, 1997, $2^{\mathrm{a}}$ ed. SP.

${ }^{11}$ Importante militante do Comitê Central do Partido Comunista Brasileiro (PCB). Fundador do Partido Comunista Brasileiro Revolucionário. (PCBR), em 1968, juntamente com Mário Alves e Apolônio de Carvalho. Morreu aos 90 anos, no dia 11 de junho de 2013. 
era aliar a formação política à prática. Considerado por muitos como um dos mais importantes historiadores marxistas do Brasil, Gorender escrevia com a autoridade de quem conheceu os porões da ditadura, foi preso e torturado pelo regime militar.

[...] A análise marxista mais conhecida sobre o golpe de 1964 provém de Jacob Gorender. Combate nas Trevas, livro divulgado em 1987, tinha por objetivo central o estudo da esquerda em geral e da luta armada em particular. Gorender enfatizou a "ameaça à classe dominante brasileira e ao imperialismo" que representava a "luta armada" no Brasil. ${ }^{12}$

Gorender, ao contrário de muitos autores considerados de esquerda, que preferem indicar a inexistência de uma situação de risco que antecedesse ao golpe militar/civil de 1964, destaca que no período que antecedeu ao golpe havia sim uma pré-disposição da esquerda radical brasileira em tomar o poder através de uma revolução; portanto existia sim uma real "ameaça à classe dominante brasileira e ao imperialismo".

[...] Nos primeiros meses de 1964 esboçou-se uma situação pré-revolucionária e o golpe direitista se definiu, por isso mesmo, pelo caráter preventivo. A classe dominante e o imperialismo tinham sobradas razões para agir antes que o caldo entornasse. ${ }^{13}$.

A censura à imprensa durante o regime militar, mais especificamente durante o período de maior intensificação da resistência armada ao governo militar, também foi objeto de estudo e fascina intelectuais de diversos campos do saber. Verificar como a imprensa lidou com a chamada censura prévia, como era a convivência entre os jornalistas e os censores do governo nas sedes dos principais editoriais da grande imprensa; quais foram as estratégias utilizadas para se burlar esta censura e demonstrar para o leitor que tais assuntos eram proibidos e estavam censurados; tudo isso instiga o pesquisador e o convida a mergulhar num emaranhado mundo onde a informação e a manipulação da verdade através da palavra escrita se tornou uma ferramenta importante na luta pela manutenção do poder.

\footnotetext{
${ }^{12}$ FICO, Carlos. Op. cit., p. 49.

${ }^{13}$ GORENDER, Kacob, apud FICO, Carlos. Op. cit., p.49. 
Toda censura impede que se circulem as notícias e, em consequência, a formação das idéias e análise crítica sobre determinado tema. A censura durante o regime militar acobertava a violência cometida contra os opositores ao regime. A censura era multifacetada, ora explícita direta e com remetente certo; ora oculta escamoteada em bilhetinhos circulando de mão em mão dentro das redações, com proibições sem mesmo se saber quem as havia determinado. Às vezes eram proibições inquestionáveis, atendidas ao pé da letra e muitas das vezes ampliadas para outros assuntos correlatos por iniciativa da própria direção do jornal que não queria se comprometer com os Órgãos de Segurança e Informação ou com a justiça militar.

Em A Censura Política na Imprensa Brasileira (1968-1978) ${ }^{14}$, Paolo Marconi traz uma análise do comportamento da imprensa brasileira que sofreu não só com a censura oficial dos órgãos de segurança, mais, sobretudo com a chamada censura patronal, "[...] feita até com maior rigor, persistência e eficácia"15. Essa obra apresenta uma análise crítica do papel e do comportamento da imprensa durante o regime militar, sob a ótica de quem vivenciou, como jornalista, os tempos mais difíceis daquele período, onde o não pensar, o não informar e o não questionar eram as regras do jogo. $\mathrm{O}$ autor apresenta uma série de cópias de documentos da censura que chegavam as redações dos principais jornais e revistas do país, bem como uma relação de conteúdos proibidos e das uma ordenação esquemática das principais ordens recebidas.

\section{- discurso da imprensa, a censurae a construção da realidade duranteo regime militar}

Num contexto de conflito político em que estava mergulhado o Brasil após 1964, a utilização dos meios de comunicações era vital para a manu-

\footnotetext{
${ }^{14}$ MARCONI, Paolo. A Censura Política na Imprensa Brasileira (1968-1978). São Paulo: Global, 1980.
}

${ }^{15}$ Idem, p. 11. 
tenção da ordem imposta pelos militares. Os jogos com as palavras faziam toda a diferença no resultado final, ou seja, na percepção do leitor. As palavras eram tecidas como que "fios ideológicos" que serviam para toda a trama das relações sociais e em todos os domínios. A palavra assumia conotação diferente em função do contexto em que era utilizada. Dessa forma, a substituição de palavras como, guerrilheiro por terrorista; assalto por expropriação; grupo por bando; assassinato por "justiçamento" ou suicídio; contestação por subversão; oposição política por inimigo interno etc., eram artifícios utilizados para desqualificar e deslegitimar um dos lados no jogo conflituoso pelo poder.

Havia, naquele período, uma situação de controle social específico sobre determinados temas e uma campanha informativa, ideologicamente preparada sob a luz da Doutrina de Segurança Nacional, que passava da situação de comunicação mais "normal" da vida cotidiana do país, para a produção e difusão diária de mensagens de massa, principalmente com o intuito de mascarar os fatos em detrimento da realidade dos mesmos.

O controle acirrado dos meios de comunicação foi determinante para o desmantelamento das organizações de esquerda que aderiram à luta armada no Brasil na década de 60, funcionando como um excelente meio de controle social. A manipulação da palavra escrita, da informação e das notícias através do controle dos meios de comunicação de massa, possibilita e

[...] reforça o controle social nas grandes sociedades urbanas, nas quais o anonimato das cidades enfraquecem (sic) os mecanismos do comportamento anormal, ligados ao contato informal face a face" ${ }^{" 16}$.

Aquino $^{17}$ destaca que na história republicana do Brasil, somente em dois momentos a ação da censura política se deu de forma contínua, sendo exercida de maneira constante durante um período determinado: no Estado

${ }^{16}$ WRIGHT, 1960, apud WOLF, Mauro. Teorias das comunicações de massa. São Paulo: Martins Fontes, 2003, p.56.

${ }^{17}$ AQUINO, Maria Aparecida de. Censura, imprensa, estado autoritário (1968/1978). São Paulo: EDUSC, 1999. 
Novo, de Getúlio Vargas (1937-1945), e durante o regime militar ${ }^{18}$ instaurado em 1964, sendo que nesse último período, o marco da censura foi lentamente instituído a partir de 13 de dezembro de 1968, com o AI5. "Na data da edição do Ato, o ESP, [O jornal Estado de São Paulo] preparou o editorial "Instituições em Frangalhos", que acabou sendo responsável pela apreensão de O ESP e do Jornal da Tarde". ${ }^{19}$.

Num primeiro momento, no início da repressão aos meios de comunicação, a censura atuava indistintamente sobre todos os periódicos; entretanto, "De 1968 a 1972 tem-se uma fase inicial em que há uma estruturação da censura, do ponto de vista legal e profissional, em que o procedimento praticamente se restringe a telefonemas e bilhetes enviados às redações" ${ }^{20}$.

Segundo Aquino, entre 1968 e 1978 a censura agia de duas formas: através de telefonemas diretos às redações - anônimos ou não - e ordens escritas - apócrifas ou não - direcionadas aos jornais de grande circulação diária, e ainda, através de "acordos" prévios fechados com os proprietários dos grandes jornais, nos quais foi instituída à chamada censura prévia ${ }^{21}$.

Instalando os censores na redação do periódico, sendo que estes, após a preparação de todas as matérias realizavam uma leitura, selecionando e cortando aquilo que, segundo suas instruções, não poderia ser divulgado. Esse foi o caso de o ESP e do Jornal do Brasil, cujas redações conviveram com os censores diariamente ${ }^{22}$.

${ }^{18}$ É comum a utilização do termo "Estado Autoritário" para referenciar o regime político instalado no Brasil no pós-64. No entanto, alguns autores recorrem a outras terminologias para designar aquele período, como é o caso de Maria Helena Moreira Alves, em Estado e Oposição no Brasil, que utiliza o termo "Estado de Segurança Nacional".

${ }^{19}$ AQUINO, Maria Aparecida de. Op. cit., p. 206.

${ }^{20}$ Em relação aos bilhetes e ordens telefônicas, baseando-se nos dados levantados por Paolo Marconi computam-se 497 registros entre 1969 e 1974. Todas as ordens eram transcritas nos chamados "livros negros", onde eram registradas as ordens recebidas dos órgãos de seguranças e pelos censores nas redações. AQUINO, Maria Aparecida de. Op. cit., p. 212.

${ }^{21}$ A censura prévia foi aplicada naqueles jornais que não respeitavam as ordens dos órgãos de segurança e continuavam a publicar matérias ou assuntos que incomodavam o Governo Militar.

${ }^{22}$ AQUINO, Maria Aparecida de. Op. cit., p. 224. 
Em periódicos não diários, a censura era mais complexa, pois todo o material deveria ser enviado previamente para Brasília ou entregue pessoalmente na delegacia regional da Polícia Federal mais próxima da redação.

Como uma forma de resistir às investidas dos órgãos repressores da imprensa, e como uma forma de denunciar a repressão sofrida, alguns jornais preenchiam os espaços cortados pelos censores com uma tarja preta, com espaços vazios ou até com assuntos que causassem estranheza ao leitor.

Tal resistência adquiriu contornos mais nítidos e contundentes nas variadas e criativas formas de substituir os espaços deixados pelos cortes da censura. A estratégia de denuncia ultrapassou a mera dimensão temporal e, hoje, já faz parte da memória coletiva do país ${ }^{23}$.

Quem sofreu mais com a repressão da censura foram os jornais da denominada imprensa alternativa, que juntos faziam coro de oposição clara e explícita ao regime militar. Os mais expressivos exemplos de imprensa alternativa daquele período, todos extintos pela repressão foram: Pasquim, Opinião e Movimento.

Em seu livro Censura, Imprensa e Estado Autoritário (1968-1978), o Exercício cotidiano da dominação e da resistência $O$ Estado de São Paulo e Movimento, EDUSC: 1999, a Historiadora Maria Aparecida de Aquino retrata bem o processo de censura prévia e da auto-censura imposta ao Jornal o Estado de São Paulo,

[...] Em entrevista (11 Set 1989), com o professor e jornalista Oliveira S. Ferreira - na época, editor-chefe e, posteriormente, um dos diretores de O ESP (O Jornal O Estado de São Paulo) - aludiu ao fato de que eram comuns os telefonemas às direções do jornal, acentuando o que não poderia ser veiculado pelo mesmo. Portanto, durante certo tempo (1968 a 1972), O ESP acedeu em acatar ordens telefônicas até a ruptura, quando se instaurou a censura prévia. ${ }^{24}$.

Já a partir de 1968, principalmente após a edição do $5^{\circ}$ Ato Institucional em 13 de dezembro, as represálias aos meios de comunicações que

\footnotetext{
${ }^{23}$ Idem, p. 256.

${ }^{24}$ Idem, p. 54 (grifo nosso).
} 
não cumpriam as ordens das autoridades se intensificaram, e eram comuns as apreensões de jornais e revistas que continham, aos olhos dos censores, artigos ou notícias que afrontavam o regime militar.

Na noite de 13 de dezembro, o jornal [O Estado de São Paulo] recebe a visita da Polícia Federal que sugere a alteração do famoso editorial "Instituições em Frangalhos"; a postura do jornal é de resistência e recusa o que motiva a apreensão"25.

Aquino relata que durante a abertura da $11^{\text {a }}$ Semana de Estudos de Jornalismo na Universidade de São Paulo, em 1970, discursando sobre o tema "Censura e Liberdade de Imprensa", numa resposta sobre a liberdade de imprensa no Brasil a um dos presentes na platéia, o jornalista e diretor do jornal o Estado de São Paulo, Júlio Mesquita Neto respondeu:

Se o senhor lê o Estado de São Paulo, sabe que o jornal vem sendo editado praticamente sob protesto. Desde o dia 13 de dezembro de 1968 que não publicamos nosso primeiro editorial. Não comentamos matéria política por não dispormos de liberdade suficiente para dizer o que pensamos. O senhor aludiu à liberdade de publicação de notícias. Como jornalista, conhece o assunto. A verdade é que há uma censura e que essa censura frequentemente não permite a divulgação de uma série de fatos. Temos de agir nesse contexto. Publicamos o que, dentro do possível, podemos, e chegamos ao ponto de ter edições apreendidas na boca da rotativa. Isso aconteceu quando, num momento de excepcional gravidade, fizemos um editorial sobre a situação geral do país. É um fato. Contra a força não há argumentos. ${ }^{26}$

Várias revistas de circulação semanal também sofreram censura, como foi o caso da Revista Veja, que teve inúmeros exemplares apreendidos por agentes da Polícia Federal. Com uma chamada "Para o agente do DOPS a revista era comunista”, no dia 12 de setembro de 1968, o Diário do Paraná anunciava a apreensão de um leitor da Revista Veja, logo após a chegada do seu primeiro exemplar nas bancas.

[...] O diário informou que um policial do DOPS tentou prender um jovem que lia a revista na rua - a primeira capa de Veja, sobre a crise no

\footnotetext{
${ }^{25}$ Idem. ${ }^{26}$ Idem, p. 54. 
bloco soviético tinha a foice e o martelo (o símbolo comunista) sobre um fundo vermelho. De acordo com o jornal o leitor da revista comunista não aceitou entregá-la e foi agredido. ${ }^{27}$

Em vários estados brasileiros a censura dos órgãos federais se fazia presente e ativa. Em Belo Horizonte, logo após a edição do AI5, a Revista Veja sofria nova apreensão.

Esse Telex, enviado em 16 de dezembro de 1968, pela sucursal de VEJA em Belo Horizonte à redação, em São Paulo, informava que a Polícia Federal estava apreendendo as revistas nas bancas de Minas Gerais, fato que, naquela manha, se repetia em todo o território nacional. A edição confiscada tinha como tema principal o anuncio do AI5, estampando na capa uma foto do Presidente Costa e Silva sozinho no Congresso. ${ }^{28}$

Antes da publicação daquela revista, um agente "sensor" já havia visitado a redação e vetado a publicação de algumas declarações de políticos sobre o novo Ato Institucional.

Não adiantou, aquela edição foi banida das bancas de forma definitiva. A Editora Abril não recebeu nenhuma justificativa para a medida. O recolhimento da edição de Veja sobre o AI5 marca o início de um longo período de convivência com a censura, seriam oito anos de temas vetados, cortes nas reportagens e presença constante de sensores na redação. ${ }^{29}$

Ao Ministério da Justiça cabia, através de decretos-leis, o respaldo legal de controle das informações veiculadas na imprensa de uma forma geral,

[...] com efeito, pelo Art. 50 do projeto, o Ministro da Justiça, por ato de império, tem a faculdade, entre outras, de determinar a apreensão de jornais e até de suspender-lhes a impressão, desde que, a seu talante, entenda que a publicação "constitua ou possa vir a constituir o meio de perpetração de crimes previstos na Lei de Segurança ${ }^{30}$.

\footnotetext{
${ }^{27}$ Memória do Regime Militar. O Brasil de 1968 a 1985 nas páginas de Veja. Disponível em www.veja.abril.com.br//especiais/regime-militar. Acesso em 2009.

${ }^{28}$ Idem.

${ }^{29}$ Idem..

${ }^{30}$ MORAES FILHO, Antônio Evaristo de. Lei de Segurança Nacional. Um atentado à liber- 
Esse amparo legal apresentava vários instrumentos que cerceavam o exercício do direito de livre manifestação do pensamento, o que resulta num atentado à liberdade de imprensa.

[...] no Art. 14, pune-se a quem "divulgar", por qualquer meio de comunicação social, notícia falsa, tendenciosa, ou fato verdadeiramente truncado ou deturpado, de modo a indispor ou tentar indispor o povo com as autoridades constituídas ${ }^{31}$.

Os meios de comunicação de massa constituem um universo simbólico que é objeto de consumo em grande escala. "Os Mass Media exprimem uma experiência individual cotidiana num terreno de conflito político, e um sistema de mediação cultural e de agregação social" ${ }^{32}$.

Segundo Motter $^{33}$ a imprensa escrita de circulação diária tem por objeto a exclusão da intervenção do sujeito, haja vista que os fatos são apresentados de forma sintética, cabendo ao jornalista apenas registrá-los.

A indústria da informação cria no cidadão o sentimento de estar bem informado, no entanto, elimina sua dimensão crítica uma vez que não permite que este tenha acesso às várias versões dos fatos, privilegiando uma visão unilateral, sintetizada, que interessa a um determinado grupo, naquele período, aos militares.

A cultura fornecida pelos meios de comunicação de massa não permite que as classes assumam uma posição crítica face a sua realidade. [...] anulam os mecanismos de reflexão e crítica para acionarem a percepção e os sentidos (visão e audição) ${ }^{34}$.

No lugar da liberdade autêntica que permitisse uma reflexão crítica dos principais acontecimentos durante o regime militar, o que era ofertado

dade. Rio de Jneiro: Zahar, 1982, p. 56.

${ }^{31}$ Idem.

${ }^{32}$ WOLF, Mauro. Op. cit., p. IX.

${ }^{33}$ MOTTHER, Maria Lourdes. Ficção e história: imprensa e construção da realidade. São Paulo: Arte \& Ciência Vilipress, 2001.

${ }^{34}$ FREITAG, Bárbara. Teoria crítica ontem e hoje. São Paulo: Brasiliense 1990, p. 73 
ao leitor era uma falsa liberdade, com informações manipuladas que encobriam os fatos reais, procedimentos comuns durante a vigência de regimes autoritários onde "[...] saber, política e economia constituem uma força cuja filosofia é a acumulação e cuja prática é a repressão de tudo o que se opunha a ela"35.

No regime militar implantado no Brasil em 64, os conflitos de classe, as lutas para modificar a ordem social e política vigente foram silenciadas em nome da "Segurança Nacional". Freitag ${ }^{36}$ destaca que nessas condições, os detentores do poder se utilizam de quaisquer artifícios para a manutenção do status quo, onde estes procuram,

[...] legitimar também o sistema político que lhe assegura estabilidade e continuidade, disfarçando o mal-estar real gerado pelas condições de unidimencionalização e confundindo as consciências, incapazes de avaliar o processo. ${ }^{37}$.

Nessa complexa relação entre a imprensa e a sociedade como um todo, há uma estrutura capaz de detectar as ameaças que o livre fluxo de informações possa representar para a estrutura fundamental da própria sociedade. A difusão de notícias sobre as tensões e conflitos sociais e políticos que afligem a sociedade num dado momento histórico, pode gerar pânico naqueles leitores desprovidos de uma visão de totalidade dos fatos e que não possuem uma "vigilância consciente".

A manipulação das informações pode criar um ambiente propício à disseminação de falsas realidades, criando nos leitores o que Wolf classifica de "disfunção narcotizante".

O cidadão interessado e informado pode sentir-se satisfeito com tudo o que sabe sem se dar conta de que se abstêm de decidir e agir. Em suma, ele considera o seu contato mediato com o mundo da realidade política, a leitura ${ }^{38}$.

\footnotetext{
${ }^{35}$ Idem, p. 94.

${ }^{36}$ Idem.

${ }^{37}$ Idem, p. 96.

${ }^{38}$ WRIGHT, 1960, apud WOLF, Mauro, Op. cit., p. 56. 
A influência da linguagem escrita sobre a construção da realidade suscita discordância por parte dos teóricos. Para alguns a linguagem cria uma imagem da realidade; para outros, porém, ela é o próprio reflexo desta realidade. A linguagem expressa nos jornais diários é socialmente transmitida ao indivíduo humano formando a base necessária de seu pensamento, uma base que permite ligar-se aos outros membros da mesma comunidade, bem como criar uma representação mental e intelectual da realidade que lhe é apresentada. ${ }^{39}$.

O discurso da imprensa durante o período ditatorial militar no Brasil esteve, na maioria das vezes, estreitamente afinado com o discurso dos militares, haja vista a existência de vários mecanismos de coação, coerção, censuras e controle dos órgãos de informação e segurança. As notícias sobre as ações dos grupos de guerrilha eram estrategicamente articuladas e manipuladas, visando desqualificar e criminalizar aqueles movimentos. A manipulação da linguagem escrita era uma forma eficaz de atingir e desarticular qualquer possibilidade de adesão de simpatizantes à causa revolucionária da esquerda, confundindo a opinião pública ao não permitir que o leitor tivesse acesso a totalidade das informações sobre determinados temas, onde,

[...] o conceito de discurso despossui o sujeito falante de seu papel central para integrá-lo nos funcionamentos de enunciados, de textos, cujas condições de possibilidades são sistematicamente articuladas sobre função ideológica. ${ }^{40}$.

O discurso jornalístico está sempre atuando junto com grandes forças políticas, econômicas e sociais, pois,

[...] um conglomerado jornalístico raramente fala sozinho. Ele é ao mesmo tempo a voz de outros conglomerados econômicos ou grupos políticos que querem das às suas opiniões subjetivas e particulares o foro de objetividade, já que criar jornais é encontrar uma forma de elevar a uma alta potência o interesse que têm indivíduos e grupos em afirmar publicamente opiniões e informações. É uma forma de dar eco a posições pessoais, de classes ou de nações através de um complexo industrial-tecnológico, que além de preservar

\footnotetext{
${ }^{39}$ MOTTER, Maria Lourdes. Op. cit.

${ }^{40}$ MAINGUENEAU, apud MOTTER, Maria de Lourdes. Op. cit., p. 22. 
uma suposta impessoalidade, afirma-se, pelo seu poder e soberania, como 'a verdade'. ${ }^{41}$.

A apropriação, controle e uso pelo Estado dos meios de comunicação de massa, foram primordiais na luta dos governos militares contra os insurgentes. A idéia de uma imprensa livre e objetiva que normalmente norteia um discurso ligado à representatividade de todos os setores sociais foi colocada à margem, onde os detentores do poder se viam ameaçados por quaisquer informações que fossem contra a "Segurança Nacional".

Para Lefebvre ${ }^{42}$, o papel do Estado como gestor da sociedade repousa sobre o cotidiano, tem por base a cotidianidade que ele gera das mais diversas formas indiretamente e diretamente através de leis, regulamentos, proibições, intervenções, fiscalizações, instituições jurídicas, orientação dos meios de comunicação, controle das informações, etc.

O discurso jornalístico, por trazer notícias diárias, num grande e complexo ciclo de informações novas, deixa a sensação, no mundo do senso comum, de que não há motivos nem espaço para desconfiança. A realidade dos fatos apresenta-se no jornal do dia, de forma superficial, fragmentada, articulada e espetacular, de forma que

[...] chegamos assim a uma forma de poder do jornal como agente do processo social: o de intervir no curso dos acontecimentos pelo uso autorizado da palavra que estrutura, sustenta e reproduz o sistema engendrado do poder. ${ }^{43}$

Grande parte da imprensa no Brasil ${ }^{44}$ durante o regime militar vivia este com este dilema constante,

${ }^{41}$ MARCONDES FILHO, C. O capital da noticia. São Paulo: Ártica, 1986, p. 10.

${ }^{42}$ LEFÉBVRE, H. apud NETTO, J. P, FALCÃO, M. C. Cotidiano: conhecimento e crítica. São Paulo: Cortez, 1989, p. 16.

${ }^{43}$ MOTTER, Maria Lourdes. Op. cit., p. 63,

${ }^{44}$ Não trataremos aqui da imprensa chamada de "alternativa". Denomina-se Jornalismo alternativo a prática jornalística feita por veículo e instituições fora do campo da mídia oficial. A imprensa alternativa cabia cobrir os fatos com informações ignoradas ou negligenciadas pela mídia hegemônica. Entre os principais meios de informação alternativos durante o regime militar destacaram-se O Pasquim e Opinião, ambos do Rio de Janeiro; O Movimento, de São Paulo e, Resistência de Belém do Pará. 
[...] Noticiar ou omitir, denunciar ou calar, tomar partido a favor ou contra, transformar insignificâncias em grandes acontecimentos para a notícia de interesse não seja notada. Distrair quando convém aos seus interesses, chamar atenção e polemizar quando lhe parece útil. Fazer avançar movimentos sociais ou refreá-los, estimular a consciência crítica ou promover o conformismo, fazer aflorar a realidade concreta e as desigualdades ou apagar os conflitos pela omissão tendenciosa das arbitrariedades, exploração e opressão decorrentes da dominação exercida por uma classe sobre as outras. ${ }^{45}$

Segundo Adorno (1954) "os meios de comunicação de massa não são simplesmente a soma total das ações que descrevem ou das mensagens desenvolvidas por essas ações". Os meios de comunicação de massa consistem em vários significados sobrepostos uns aos outros, onde todos colaboram para o resultado final. Todo o processo de produção de uma notícia faz parte de uma estrutura capaz de manipulação das palavras, conforme interesses políticos, sociais e econômicos que estão em jogo.

A análise de estudo dos efeitos das mensagens dos meios de comunicação de massa, devem ter a noção dessa possibilidade dos efeitos efetivos das mensagens ocultadas. Wolf ${ }^{46}$ destaca que "as relações entre os diferentes níveis (manifestos e latentes) das mensagens não são de modo algum simples de serem aprendidos e estudados". Durante a luta armada no Brasil, a imprensa foi utilizada como forma de ocultar a verdade, manipular as informações e desvirtuar e criminalizar os movimentos sociais de contestação ao regime.

O processo de comunicação presente na relação imprensa e sociedade tomam uma forma intencional, ou seja, os produtos da mensagem, o comunicador, em geral, utilizam-se desse poder para alcançar determinados objetivos, buscando um efeito na percepção do seu leitor. Como a luta armada no Brasil teve características de uma "guerra de guerrilha", a utilização da informação era decisiva nas tomadas de decisões estratégicas, tanto por parte dos militares, como, também, dos guerrilheiros.

\footnotetext{
${ }^{45}$ MOTTER, Maria Lourde. Op. cit., p. 63.

${ }^{46}$ WOLF, Mauro. Op. cit.
} 
Os órgãos repressores precisavam de ajuda da população, como informações sobre atitudes e movimentações suspeitas de pequenos grupos de homens e mulheres. Para tanto, necessário se fez transformar os movimentos contestatórios ao regime em ilegais, criminalizando-os e fazendo crer que estes ofereciam perigo real ao cidadão comum.

Nessa guerra de informação e contra-informação, ambos os lados faziam de tudo para angariar o apoio e a simpatia da população. Eram comuns a divulgação de cartazes e informações sobre os "terroristas". Os órgãos repressores espalhavam o terror e o medo, fazendo com que a população se tornasse sua aliada.

Num ambiente conturbado onde o não penar criticamente, o não expressar-se e a omissão involuntária de divulgação de idéias eram as regras impostas pelo regime militar, a realidade, ou melhor, a percepção da realidade que ficava no imaginário era aquela ofertada nas páginas dos jornais de grande circulação diária, onde até a discussão entre os leitores sobre este ou aquele acontecimento se tornava um ato perigoso, que poderia ser interpretado como ato subversivo atentatório a segurança nacional.

As consequências em longo prazo desse processo de informação controlada podem formar uma consciência coletiva onde "[...] as comunicações não intervêm diretamente no comportamento explícito; de preferência, tendem a influenciar o modo de como o destinatário organiza a própria imagem do ambiente". ${ }^{47}$.

Os efeitos da informação controlada podem levar o indivíduo a modificar a própria representação da realidade social. A eficácia da forma de divulgação das notícias pela imprensa consiste na sua capacidade de modificar a imagem daquilo que considera ou não que poder ser noticiado. A este respeito, o controle acirrado da imprensa durante o regime militar estava ligado a uma estrutura capaz de filtrar, estruturar e enfatizar determinados temas ou notícias, em nome da segurança nacional.

${ }^{47}$ ROBERTS, 1972, p.361, apud WOLF, Mauro. Op. cit. p.138. 
Assim, a manipulação ideológica por parte de um segmento da imprensa naquele período, desempenhou uma função de construção da realidade, da realidade que convinha aos militares. Quanto a seus efeitos,

[...] a influência da mídia é postulada, uma vez que esses efeitos nos ajudam a estruturar a imagem da realidade social, durante o longo período, a organizar novos elementos dessa imagem, a formar novas opiniões e crenças $^{48}$.

[...] os meios de comunicação de massa estruturam uma realidade mais vasta, não local, da qual é difícil subtrair-se; [...] Há algo de invasor em relação ao que a mídia apresenta, algo que torna sua influência cumulativa $^{49}$.

.Durante o regime militar, as notícias e os temas que iriam chegar aos leitores faziam parte da "ordem do dia", os quais sofriam uma classificação hierárquica de suas importâncias e prioridades. Os assuntos inerentes à luta armada e às questões políticas tinham uma prioridade nas análises dos censores e na censura prévia.

A informação impressa é organizada em torno dos fatos históricos, em torno da memória dos acontecimentos, onde a produção das informações é classificada em temas, por suas relevâncias, a juízo dos detentores dos meios de produção das mesmas. Cabe, assim, aos editores chefes a tarefa de aprofundar, contextualizar e ampliar as notícias de acordo com seus interesses ou com as ordens que recebe.

Num contexto de censura prévia ou velada, temos um tipo de "deformação", manipulação dos conteúdos informados. No entanto isto não pode ser imputado a violação da autonomia profissional, mas sim às circunstâncias em que a informação é produzida e organizada, a que fins ela se destina. No regime militar, tanto os conteúdos dos jornais, como o trabalho de seleção das notícias, passavam pelo crivo dos censores da ditadura, os quais ceifavam o que era considerado nocivo ou ameaçador ao regime.

${ }^{48}$ Idem, p. 141.

${ }^{49}$ LANG, 1962, p.698, apud WOLF, Mauro. Op. cit., p.142. 
[...] o conceito de manipulação implica uma posição de equilíbrio, da qual as notícias podem ser tiradas devido à influência do preconceito, da conspiração ou da decisão dos que detêm o poder político ou comercial. ${ }^{50}$.

Uma peculiaridade da produção de informação para a publicação em jornais de circulação diária é a de que os eventos noticiáveis devem ter ocorrido nas 24 horas entre um noticiário e outro. Durante o regime militar no caso das notícias referentes à luta armada, o registro das notícias era protelado sob a alegação de que sua divulgação poderia frustrar uma investigação em curso ou uma operação sigilosa.

Dentre as fases de coleta de matérias que darão suporte à informação jornalística diária, a fonte das informações possui um lugar de destaque neste processo. Numa situação de "normalidade", o jornalista iria à busca das notícias, do que seria interessante ao leitor. Já no processo de produção de notícias censuradas previamente, estas chegam aos jornalistas já prontas, moldadas ideologicamente pelos critérios dos órgãos repressores.

As formas de censuras eram diversas, mas geralmente sutis, como num simples telefonema à redação dos jornais, ou por "bilhetinhos" emitidos com os conteúdos a serem cortados ou, simplesmente com os dizeres: não publicar. "[...] ordens telefônicas ou bilhetes encaminhados às redações por parte das instituições encarregadas (de modo geral, o Ministério da Justiça, por intermédio da Polícia Federal) ${ }^{51}$.

Essas flutuações nas notícias podem ser diretamente atribuídas às fontes dominadas pelo aparato repressor. Nos conflitos entre as forças federais e os grupos revolucionários durante o regime militar, a propaganda ideológica - de ambos os lados - era fator decisivo para a legitimação das ações nesse complexo exercício de poder sobre a interpretação da realidade. Fazia parte dessa guerra psicológica a mobilização da opinião pública para um dos lados. Nessa luta desigual,

${ }^{50}$ GOLDING-ELLIOTT, 1979. p.12, apud WOLF, Mauro. Op. cit., p.189.

${ }^{51}$ AQUINO, Maria Aparecida de. Censura, imprensa, estado autoritário (1964-1984). Petrópolis: Vozes, 1999, p. 22. 
[...] aqueles que possuem o poder econômico ou político podem facilmente obter acesso aos jornalistas e são acessíveis a eles; quanto aos que não tem poder, é mais difícil que se tornem fontes e sejam procurados pelos jornalistas enquanto suas ações não produzem acontecimentos noticiáveis, por serem moral ou socialmente negativas". ${ }^{52}$

A produção de notícias e registros acerca das ações de grupos revolucionários produziu uma fragmentação na imagem da realidade desses grupos, com a promoção de notícias construídas dentro de um quadro de expectativas estáveis, capazes de coordenar e manipular as reais intenções desses grupos, agindo de forma a descontextualizar os acontecimentos do âmbito social, histórico, econômico ou político no qual estavam inseridos, de onde deveriam ser interpretados.

\section{Aimprensa amordaçada e as "manobras da informação"}

Quando se trata de analisar a imprensa brasileira, nos deparamos com diversas dificuldades por se tratar de uma temática por si só espinhosa e complexa. $\mathrm{Na}$ análise dessa mesma imprensa, num momento histórico de liberdades democráticas praticamente escassas, num ambiente cercado de incertezas quanto a real identidade das pessoas dentro do jogo de posse e apropriação das palavras, tudo tornasse mais difícil.

Logo após o movimento de 31 Março/01 Abril de 1964, à luz da Doutrina de Segurança Nacional, o inimigo interno deixou de ser uma pessoa física, um nome particular, para tomar a forma de um eixo de relações de qualquer organização social ou partido político que viesse a ser concebido pelos militares como uma ameaça ao novo regime político que estava sendo implantado no Brasil.

Nos momentos iniciais do regime militar, ocorreram prisões, aberturas de Inquéritos Policiais Militares (IPM), demissões de funcionários civis,

${ }^{52}$ GANS, 1979, apud WOLF, Mauro. Op. cit., p. 81. 
aposentadorias compulsórias de professores, prisões de estudantes, reformas e prisões de militares leais ao governo deposto, cassações de políticos etc. Nesse período inicial do regime militar, a imprensa não foi censurada, haja vista que era utilizada para fazer a propaganda do movimento de 64 . Posteriormente surge a censura e a repressão aos meios de comunicação.

Pela primeira vez, desde 1964 a imprensa - que Castello Branco e mesmo Costa e Silva numa primeira fase, consideraram intocável - é atingida pela repressão, instaurando-se a censura. Muito ampla nos primeiros momentos da crise, ela se tornará um pouco mais branda tempos depois, mas não mais deixará de existir, aumentando o controle sobre as informações conforme as oscilações da situação política e social do país"53.

Na busca por legitimação do regime militar, o controle da imprensa, principalmente do jornal, tornou-se vital para disseminação da ideologia da Doutrina de Segurança Nacional. Luiz Gonzaga Motta, em seu livro Imprensa e Poder ${ }^{54}$, ressalta que "Não há poder sem imprensa, nem imprensa sem poder. Ambos estão historicamente relacionados". Dentro dessa perspectiva, cabia ao Ministro da Justiça a fiscalização vigilante e a autoridade para determinar a suspensão do processo de impressão e apreensão de tiragens inteiras de jornais, quando entendesse que a publicação "constitua ou possa vir a constituir o meio de perpetração de crimes previstos na Lei de Segurança" 55 .

Eram proibidas e controladas todas as informações sobre manifestações populares contestatórias do regime militar. Ocorrem vetos às notícias sobre os partidos opositores, principalmente aos partidos clandestinos e as ações das organizações de esquerda que aderiram à luta armada no combate ao regime militar. Eram também proibidas as notícias sobre o andamento dos IPM na Justiça Militar, principalmente os que envolviam membros das organizações e dos partidos clandestinos. "Há cortes nas matérias que veiculavam informações sobre assaltos. [...] ameaças de sequestros, narrativas

\footnotetext{
${ }^{53}$ AQUINO, Maria Aparecida de. Op. cit., p. 56.

${ }^{54}$ MOTTA, Luiz Gonzaga. Imprensa e poder. Brasília: EdUnb, 2002.

${ }^{55}$ MORAES FILHO, Antônio Evaristo de. Op. cit., p. 56. 
da morte de agentes de segurança por organizações de esquerda. [...] e críticas ao terrorismo" 56 .

Mais importante do que controlar a narrativa dos fatos que envolviam as ações das organizações de esquerda era a sua completa neutralização. A omissão da informação era conseguida, principalmente, dentro dos periódicos que aceitavam "trabalhar no limiar da autocensura".

Atuavam por meio de recados telefônicos ou bilhetes nem sempre identificados, utilizando-se de fórmulas clássicas como as expressões: "de ordem superior", "polícia federal", "pede", "fica terminantemente proibida a divulgação", "da ordem do Exmo.sr. General diretor geral da PF [Polícia Federal]", etc. ${ }^{57}$.

Os responsáveis pelas redações dos jornais que se submetiam a essas formas anônimas de censura sabiam que o não cumprimento das mesmas implicaria em represálias, tais como a presença diária de censores na redação ou mesmo na apreensão de todo o material na gráfica ou em bancas de jornal, o que gerava um enorme prejuízo financeiro.

A propaganda ideológica cumpria um papel fundamental dentro desse contexto de preservação do status quo. No Brasil sua utilização se deu antes do movimento de 64, entretanto foi mais difundida durante os longos 20 anos de regime militar. A utilização da propaganda ufanista de uma nação ordeira e progressista, tendo por referencial a máxima "Segurança e Desenvolvimento", fazia parte da estratégia da Doutrina de Segurança Nacional, bem como a necessidade de criação de um inimigo em potencial, o comunismo, "[...] estigmatizado como uma ameaça concreta e contra a qual toda a sociedade deve se lançar na defesa dos "ideais de liberdade"

A larga utilização da propaganda visava criar uma empatia da sociedade civil em relação ao Estado. Para tanto, slogans como "Brasil, ame-o ou deixe-o" e "Ninguém segura este país" eram modos de passar uma idéia de coesão, de unidade nacional, em contraposição aos oposicionistas, grupos "minoritários" que só mereciam a exclusão.

\footnotetext{
${ }^{56}$ AQUINO, Maria Aparecida de. Op. cit., p. 67.

${ }^{57}$ Idem, p. 80.
} 
A propaganda, através de seus métodos, criou um clima de simpatia ao regime e implantou a doutrina que o sustentava, a censura foi, ao lado das outros tipos de repressão, o instrumento que buscou eliminar toda possibilidade de debate, crítica e oposição. Neste sentido, propaganda e censura caminham juntas na vigência dos regimes autoritários, uma sustentando a outra. A propaganda dá suporte e sustentação à censura, e esta favorece aquela, permitindo-lhe uma maior eficácia pela eliminação de qualquer possibilidade de instância crítica." 58

Marilena Chauí ${ }^{59}$ (19 afirma que o indivíduo participa da vida social e política na proporção ao volume e ao acesso quantitativo e qualitativo de informações que lhe são disponibilizadas. Não basta a possibilidade de acesso às informações e sua capacidade de aproveitá-las, mas, e, sobretudo, pela capacidade e da possibilidade de nelas podermos intervir como produtor do conhecimento e do saber.

Não é qualquer um que pode dizer qualquer coisa a qualquer outro em qualquer lugar sobre qualquer circunstância. Há, portanto, regras de interdição quanto ao emissor, ao receptor, à mensagem, seu tempo e seu lugar" $"$.

Durante o período da luta armada, as informações e as manipulações da palavra escrita eram vitais para a obtenção do sucesso e eram exploradas pelos dois lados daquele conflito. Ressalvadas as devidas proporções, as organizações de esquerda, principalmente durante a fase de sequestro de diplomatas estrangeiros, souberam utilizar-se bem da mídia para difundir sua ideologia e sua proposta de revolução e derrubada do regime militar.

Uma dessas oportunidades de utilização dos meios de comunicação pelas organizações de esquerda se deu com o episódio do sequestro do embaixador norte americano no Brasil, Charles Burke Elbrick, pela Ação

\footnotetext{
${ }^{58}$ PEREIRA, Antonio Aparecido. A Igreja e a Censura Política à Imprensa no Brasil: 1968/1978. Roma: Centro Internazionale per gli studi Sull' opinioni Pública (CISOP), 1982. In AQUINO, Maria Aparecida de. Op. cit.

${ }^{59}$ CHAUÍ, Marilena de Souza. Cultura e democracia: o discurso competente e outras falas. São Paulo: Cortez, 1986.
}

${ }^{60}$ CHAUÍ, 1986, apud AQUINO, Maria Aparecida de. Op. cit., p.190. 
Libertadora Nacional (ALN). Numa ação ousada na zona sul do Rio de Janeiro, em 1969, um comando de ação conjunto, ALN e MR-8, sequestrou o embaixador e exigiu a soltura de presos políticos que estavam em poder do Exército.

Foi a primeira vez que um grupo revolucionário teve acesso direto aos principais jornais do país, e conseguiu publicar, na íntegra, um longo manifesto com suas explicações para suas ações que ocorriam em várias partes do país. O manifesto foi publicado em 5 de setembro de $1969 .{ }^{61}$

Na luta pela apropriação da palavra, as verdades não são dadas pura e simplesmente, elas são manipuladas taticamente, pensadas e estrategicamente articuladas para o fim a que se destina, qual seja: o convencimento do leitor. Dessa forma, no campo do jornalismo trava-se uma verdadeira batalha em torno da conquista de espaço e confiança do leitor, onde a palavra era articulada dentro de um dado contexto, o que permitia montar-se uma verdade.

Nos anos que ocorreram as mais intensas e ousadas ações das organizações de esquerda (1968/1972), os registros de suas ações foram transferidos das páginas políticas para as páginas policiais, colocando num mesmo patamar os crimes comuns e os crimes políticos. Na tentativa de desqualificar um dos lados envolvidos no conflito, o uso da língua não constituiu um instrumento neutro, pelo contrário, sua utilização servil para convencer, desqualificar, tomar partido, denunciar, revelar, escamotear, manipular; cabendo ao enunciador o domínio do enunciado, e, desta forma, dando a narrativa dos fatos o sentido que lhes convinha. "As várias formas do discurso e seus diversos sentidos conduzem a um emaranhado de significados, nem sempre voluntários, que podem acarretar uma redefinição do próprio discurso". ${ }^{62}$.

\footnotetext{
${ }^{61}$ Para ter acesso à íntegra deste manifesto, hoje atribuído ao jornalista Franklin Martins, ver: ABREU, João Batista de. As manobras da Informação: Análise da cobertura jornalística da luta armada no Brasil. (1965-1979). Rio de Janeiro: EdUFF: 2000. p. 241.

${ }^{62} \mathrm{ABREU}$, João Batista de. As manobras da informação: análise da cobertura jornalística da luta armada no Brasil (1965-1979). Niterói: EdUFF: Mauad, 2000, p. 17
} 
Quando se trata da análise jornalística de um período conturbado como o da luta armada no Brasil, mais importante do que analisar o que está escrito é buscar enxergar o que está oculto, o "não dito". Nesse sentido devemos ter um cuidado especial com a utilização de palavras carregadas com juízo de valor sobre o fato narrado, tais como: "revolução"; "guerrilheiro", "terrorista", "golpe", "subversão", etc. ${ }^{63}$.

As ações de sequestros de diplomatas estrangeiros representaram as poucas vitórias das organizações clandestinas na luta contra os órgãos repressores, pois permitiam a divulgação de suas idéias e pretensões políticas, haja vista que houve ampla cobertura jornalística de todos os casos de sequestros, o que possibilitou aos grupos armados uma projeção nacional e internacional.

A busca pela apropriação da palavra escrita faz parte da lógica de disseminação de qualquer ideologia, onde "[...] tudo que é ideológico possui um significado e remete a algo situado fora de si mesmo. Em outros termos, tudo que é ideológico é um signo. Sem signos não existe ideologia" ${ }^{64}$.

Na realidade, não são palavras o que pronunciamos ou escutamos, mas verdades ou mentiras, coisas boas ou más, importantes ou triviais, agradáveis ou desagradáveis etc. A palavra está sempre carregada de um conteúdo ou de um sentido ideológico ou vivencial. É assim que compreendemos as palavras e somente reagimos àquelas que despertam em nós ressonâncias ideológicas ou concernentes à vida." 65

O discurso jornalístico é repleto de componentes que, vistos isoladamente, podem não transparecer o seu caráter ideológico. No conjunto, o texto, o título, o entretítulo e a foto são elementos fundamentais para uma análise do conteúdo. Outro aspecto a ser observado, principalmente em si tratando das notícias jornalísticas acerca da luta armada no Brasil é a localização da matéria na página. As notícias eram propositalmente colocadas nas páginas policiais ao lado das notícias diárias da criminalidade comum.

\footnotetext{
${ }^{63} \mathrm{Idem}$.

${ }^{64}$ BAKHTIN, 1992, apud ABREU, João Batista de. Op. cit., p.22.

${ }^{65} \mathrm{Idem}$.
} 
Assim, para o leitor "comum", a análise isolada de cada item, fragmentado e envolto a notícias da criminalidade violenta cotidiana, comprometia a percepção do todo, a análise global e a unidade do discurso.

Aos que se opunham ao regime militar era utilizada a denominação de "subversivos", ou seja, esta palavra carregava um estereótipo que poderia designar tanto aqueles que estavam realmente engajados na luta armada, quanto qualquer outro que, à luz da Doutrina de Segurança Nacional, não coadunavam com os rumos que o país estava seguindo.

Abreu $^{66}$ esclarece que o termo "subversivo" servia, inicialmente, como designação para políticos cassados e/ou para os recém-indiciados nos inquéritos militares, muito comuns no pós-64. Com o tempo, porém, este termo tornou-se uma espécie de alcunha para todo brasileiro que viesse, de uma forma ou outra, se opor ao regime militar. A utilização do termo "subversivo" era, na verdade uma estratégia dos "revolucionários de 64" tipificar os inimigos do novo governo, visando desqualificá-los perante a opinião pública.

Já o termo "terror" ou sua derivação "terrorismo", muito utilizado pela imprensa para se referir aos grupos armados, foi cunhado pela primeira vez no início da década de 1790, durante a Revolução Francesa. No período compreendido entre setembro de 1793 a julho de 1794, ocorreu o emprego de métodos violentos nas execuções daqueles que se opunham ao regime durante o Período Jacobino, onde a utilização da guilhotina era o principal mecanismo de eliminação de adversários políticos. O termo "terror" foi utilizado para designar o extermínio em massa de pessoas. Já durante o regime militar,

[...] segundo o depoimento do jornalista Alberto Diones, editor-geral do jornal do Brasil [entrevista concedida em abril de 1992, no Rio de

\footnotetext{
${ }^{66}$ ABREU, João Batista de. Op. cit.

${ }^{67}$ A idéia de uma "revolução", defendida por seus idealizadores, dava ao golpe civil/militar de 1964 uma visão não de transitoriedade, mas sim de continuísmo. Por isso a perseguição aos simpatizantes do Governo de João Goulart deposto pelos militares, o que resultou em cassações de mandatos e perseguições a civis e militares.
} 
Janeiro], a partir do AI5 o governo recomendou aos principais jornais que classificassem de terrorismo todas as ações armadas praticadas por guerrilheiros. ${ }^{68}$.

No entanto, muito antes dessa determinação, o jornal o Globo, já em 1966, classificou como "terrorismo" um atentado a bomba contra candidato à sucessão presidencial de Castello Branco, o Marechal Costa e Silva, ex-ministro da Guerra, no aeroporto de Guararapes, em Recife- PE. ${ }^{69}$

$\mathrm{Na}$ cobertura de ações que envolviam o confronto entre as forças de segurança e as organizações armadas, a estas últimas não era permitida uma resposta que visasse expressar seus pensamentos e suas tendências, até mesmo por uma questão de limitação devido à clandestinidade dessas organizações. Nem sempre era possível ouvir o "outro lado", tal qual preconiza os manuais dos jornalistas. Naquela luta desigual pelo domínio do discurso, a versão oficial era a predominante.

Na cobertura de um fato tão complexo como a luta armada, um dever de ofício do profissional do jornalismo fica ao largo, qual seja: "narrar os acontecimentos ouvindo as versões dos diversos atores envolvidos". Num contexto de censura, prisões e fechamento de editoriais, como ocorreu no período mais repressivo do regime militar (1968-1974), às circunstâncias beneficiavam os detentores dos meios de comunicação e a notícia que prevalecia quase sempre provinha dos órgãos oficiais de segurança, ficando, desta forma, a notícia restrita a uma só fonte.

O poder outorgado ao Ministro da Justiça permitia-lhe penetrar, através de seus agentes, nas oficinas de um jornal e de impedir a confecção do periódico. Com essa prerrogativa, aquela autoridade poderia exercer, sem qualquer controle, a repressão aos meios de comunicação, desde que enten-

${ }^{68}$ Idem, p. 25.

${ }^{69}$ Uma bomba foi colocada no saguão do aeroporto Guararapes, no Recife-PE. Este atentado vitimou 15 pessoas, três mortos, dentre civis e militares, e várias pessoas gravemente feridas. O atentado foi atribuído a Ação Popular, (AP), e é considerado o marco inicial da luta armada no Brasil. Ver: USTRA, Carlos Alberto Brilhante. A verdade Sufocada. A história que a esquerda não quer que o Brasil conheça. Brasília: Ed. Ser, 2006. 
desse que estava sendo a impressa portadora de uma "notícia tendenciosa" ou "um fato verdadeiro truncado ou deturpado", que viesse a contrariar os interesses do Governo ou pondo em risco a segurança nacional. Esses meios de controle das informações cerceavam o livre exercício do direito de manifestação do pensamento, o que resultava num atentado à liberdade de imprensa. $\mathrm{Na}$

cobertura da luta armada, cabia a imprensa o papel de informar sem contrariar os diversos interesses em jogo, driblar a censura e denunciar os abusos, mesmo que de forma branda e sutil. Enfim, articular as palavras de forma que os fatos fossem noticiados, mesmo que não correspondessem à verdade. "Se entendermos o fazer jornalístico como técnica de construção da narrativa, podemos concluir que o discurso jornalístico redunda mais na produção da realidade do que na sua reprodução" ${ }^{70}$.

Um fator determinante nessa relação entre o meio de comunicação e o leitor é que este, como receptor em potencial das mensagens transmitidas, não possui uma visão de mundo, mas várias visões, o que o torna um decodificador específico de cada mensagem. Nessa relação simbólica, o termômetro que mede o "grau" de receptividade e satisfação do leitor é muito subjetivo, e, na maioria das vezes se dá por meio de pesquisas de opinião ou em cartas destes às redações dos jornais.

[...] o jornal faz uso de recursos de linguagem (gráficos, fotos e texto) para conquistar seu público. Como lida com bens simbólicos- sua matéria prima é a ideologia- precisa afirmar-se como intermediário fiel entre o leitor e o acontecimento. ${ }^{71}$

O relato jornalístico se pauta numa síntese do que seja julgado mais relevante para o leitor, mas problemas como a apuração dos fatos, a natureza das fontes, o horário do fechamento fazem com que, às vezes, o essencial e relevante fiquem de fora da narrativa. Esse aspecto fica mais complexo quando o meio de comunicação sofre com a censura. $\mathrm{O}$ medo de se comprometer com a realidade dos fatos, principalmente durante a luta

\footnotetext{
${ }^{70}$ ABREU, João Batista de. Op. cit., p. 141.

${ }^{71}$ Idem, p. 142.
} 
armada, fez com que alguns profissionais do jornalismo deixassem de lado seus manuais e passassem a relatar somente as informações oficialmente recebidas dos órgãos de segurança. Essa parcialidade em determinadas notícias, quando sentida pelos leitores, comprometia a confiabilidade do meio de comunicação, ameaçando a credibilidade conquistada pelo jornal. No entanto, $\mathrm{ABREU}^{72}$ esclarece que credibilidade não significa dizer exatamente a verdade, mas contar um fato verdadeiro de acordo com a visão de mundo do receptor. "A coerência interna consiste na verossimilhança do fato narrado".

O jornal trabalha com a intervenção na narrativa, na seleção dos argumentos, na escolha dos sinônimos. A ênfase em determinados fatos no decorrer da discrição dos acontecimentos, ou a mera omissão destes, fazem, juntamente com a "não-contextualização" do momento em que o fato ocorreu, toda a diferença na interpretação final do leitor.

A riqueza da língua portuguesa permite a utilização de uma infinidade de expressões que, em princípio, não possuem o mesmo significado, mas dentro de um texto ou contexto podem ganhar um significado desejado de acordo com a apropriação que o narrador faz delas. Durante os relatos da luta armada, os usos de alguns verbos se tornaram recorrentes nas narrativas, como por exemplo: “aniquilar", "eliminar”, "torturar”, “justiçar”, “estourar", "assassinar"; todos utilizados por ambos os lados do conflito, para justificar ou acusar ações que terminavam em morte de ambos os lados.

Dessa forma, "assassinar" poderia ser noticiado como "justiçar" ou "aniquilar"; "desapropriar" poderia ser sinônimo de "assaltar" ou "roubar". A morte numa ação poderia ser anunciada com o verbo "tombar", como "tombou em combate". Segundo ABREU73, a utilização pelos órgãos de segurança de expressões como "reduto da subversão"; "trilha do terrorismo", ou ainda, "ninho de terroristas", ajudaram a compor uma referência que colocava a luta armada e as organizações nela envolvidas num rol das

\footnotetext{
${ }^{72}$ Idem.

${ }^{73}$ Idem .
} 
criminalidades comuns. Por outro lado, o verbo "justiçar" foi escolhido e acolhido pelas organizações de esquerda para justificar os assassinatos de agentes dos órgãos de segurança, empresários e, principalmente, para justificar a morte de militantes delatores.

\section{Considerações finais}

Durante quase todo o período do regime militar no Brasil, nomeando as ações das organizações armadas com expressões comuns utilizadas pela imprensa no dia-a-dia, os órgãos de segurança conseguiam nivelar as ações de guerrilheiros, de cunho político/ideológico, com ações de gangues ou quadrilhas de criminosos comuns.

Assaltos a bancos ou o sequestros de autoridades foram classificados como "atos de terrorismo", o que induzia o leitor a acreditar que tais ações significavam uma ameaça à população em geral e que eram desprovidas de uma motivação política.

Nesse processo de transmissão de uma mensagem, transmissor e receptor precisam dominar os mesmos códigos de significados, isto significa dizer que os meios de comunicação em geral, e as matérias jornalísticas em particular, precisam respeitar a "língua do público-alvo". Do contrato social entre o leitor e o jornal, esse último se coloca e é percebido como intermediário entre o poder público e o povo. Do jornal se espera a imparcialidade na narrativa do discurso, quando limites éticos são ultrapassados, surgem espaços para que a ideologia dominante faça seu jogo utilizando-se de infinitos conceitos, preconceitos, padrões de comportamentos e juízos de valores para produzir uma malha discursiva em defesa do status quo. 